\title{
Fish community structure along a conservation gradient in Bodoquena Plateau streams, central West of Brazil
}

\author{
Estrutura da ictiofauna ao longo do gradiente de conservação em \\ riachos do Planalto da Bodoquena, Centro-Oeste do Brasil
}

\section{Lilian Casatti ${ }^{1}$, Renato de Mei Romero ${ }^{1}$, Fabrício Barreto Teresa ${ }^{1}$, José Sabino $^{2}$ and Francisco Langeani ${ }^{1}$}

\author{
${ }^{1}$ Laboratório de Ictiologia, Departamento de Zoologia e Botânica, \\ Instituto de Biociências, Letras e Ciências Exatas - IBILCE, Universidade Estadual Paulista - UNESP, \\ Rua Cristóvão Colombo, 2265, CEP 15054-000, São José do Rio Preto, SP, Brazil \\ e-mail: licasatti@gmail.com, romerobio@yahoo.com.br, \\ fabricioteresa@yahoo.com.br, langeani@ibilce.unesp.br
}

${ }^{2}$ Laboratório de Biodiversidade e Conservação de Ecossistemas Aquáticos, Universidade Anhanguera - Uniderp, CEP 79037-280, Campo Grande, MS, Brazil e-mail: sabino-jose@uol.com.br

\begin{abstract}
Aim: To investigate whether composition and structure of stream ichthyofauna vary along the conservation gradient in the Bodoquena Plateau; Methods: Standardized sampling was performed in nine stream stretches (three references, three in the pasture, and three in urban areas), each $80 \mathrm{~m}$ long, in April, May and June/08; Results: A quantity of 8,102 individuals representing 36 species was collected. There were no significant differences with respect to absolute species richness among stretches. Urban stretches were more similar to each other than the other two groups, both regarding species composition and abundance. A set of six species was considered an indicator of reference stretches, whereas two were of pasture stretches and four of urban stretches. Poecilia reticulata and Corydoras aeneus, occurring only in urban stretches, were unique in showing the maximum values in the indicator species analysis; Conclusions: Results indicate changes in the ichthyofauna with urbanized surrounding water courses. The presence and abundance of Poecilia reticulata and Corydoras aeneus may indicate the quality loss of these environments.
\end{abstract}

Keywords: species richness, Bonito, indicator species, reference, pasture, urban area.

Resumo: Objetivos: Investigar se a composição e estrutura da ictiofauna em riachos variam ao longo do gradiente de conservação dos riachos do Planalto da Bodoquena; Métodos: Foram realizadas amostragens padronizadas em nove trechos de riachos (três referências, três em meio à pastagem e três em área urbana), com $80 \mathrm{~m}$ de extensão cada, nos meses de abril, maio e junho/08; Resultados: Foram coletados 8.102 indivíduos de 36 espécies. Não houve diferenças significativas com relação à riqueza absoluta nos trechos referência, de pastagem e urbanos. Os trechos urbanos foram mais semelhantes entre si do que entre os dos demais grupos, tanto com relação à composição de espécies quanto à abundância. Um conjunto de seis espécies foi considerado indicador nos trechos referência, enquanto que duas foram nos trechos de pastagem e quatro em trechos urbanos. Poecilia reticulata e Corydoras aeneus, de ocorrência restrita aos trechos urbanos, foram as únicas a apresentar os valores máximos do índice de espécies indicadoras; Conclusóes: Os resultados indicam alteraçôes na estrutura da ictiofauna com a urbanizaçấo no entorno dos cursos d'água. A presença e abundância de Poecilia reticulata e Corydoras aeneus podem ser indicadores da perda de qualidade destes ambientes.

Palavras-chave: riqueza de espécies, Bonito, espécie indicadora, referência, pastagem, área urbana. 


\section{Introduction}

Fragmentation and environmental degradation process in Brazilian territory is linked to economic and urban development (Gonçalves et al., 2003). Because of this, aquatic environments have been exposed to several disturbance levels related to water demand for irrigation, industrial, domestic, and recreation usage (see Saunders et al., 2002), and even changes in the basic hydrology of the water courses, changes in habitat and energy sources, affecting everything from small streams to large rivers (Araújo, 1998).

The Bodoquena Plateau region, in the State of Mato Grosso do Sul, has rare aquatic environments and is ecologically fragile, with high aquatic biodiversity and a high degree of endemism, which are the results of a complex combination of geological and evolutionary processes (Sabino and Trajano, 1997; Scremin-Dias et al., 1999; Sabino, 2002, 2005). These small streams and springs of crystalline water are invariably subjected to a series of potentially degrading activities, such as the suppression of native Cerrado (open formation vegetation) areas in the Bodoquena Plateau to building cities and implanting monocultures and pastures.

Few developing countries have the financial resources to sustain long-term monitoring of its watersheds. In Brazil, historically, the assessment of impacts on freshwater environments has focused on water quality and the criteria of classification are solely based on physical and chemical factors (Brasil, 2005). However, chemical analyses of water are relatively expensive and only partially reflect the environmental impacts (Plafkin et al., 1989).
Therefore, the development and implementation of protocols that facilitate monitoring of biological and ecological attributes (Yoder and Rankin, 1994) are recommended.

When compared to other Brazilian ichthyofaunistic provinces (e.g., Alto Rio Paraná system), the fish fauna of the Central-West can still be considered poorly known. However, recent efforts have been directed to improve the taxonomic knowledge of the fish, as exemplified by the Bodoquena Expedition-2004, which received formal support from the Smithsonian Institution (Washington D.C.) and Fundação Manoel de Barros (Campo Grande, MS). Therefore, considering recent advances in the taxonomy of the regional fish fauna, the purpose of this study was to identify ecological descriptors of fish assemblages that reflect the conservation state of streams in this region. These results may serve as a basis for the refinement of impact monitoring techniques, notably the development of biotic integrity indices. Specifically, we evaluated whether the composition and structure of fauna vary according to a conservation gradient represented by different land uses along the streams (forests, pasture, and urban areas).

\section{Material and Methods}

\section{Study area}

The study was conducted at nine stream stretches located in Bodoquena Plateau (Figure 1), southwest of the Mato Grosso do Sul State. The region is drained by the Paraguay River basin (Willink et al., 2000), which is included in the La Plata-Uruguay-Paraguay-Paraná system, the second largest $\left(3.2\right.$ million $\left.\mathrm{km}^{2}\right)$ drainage system in South America (Lowe-McConnell, 1987). The

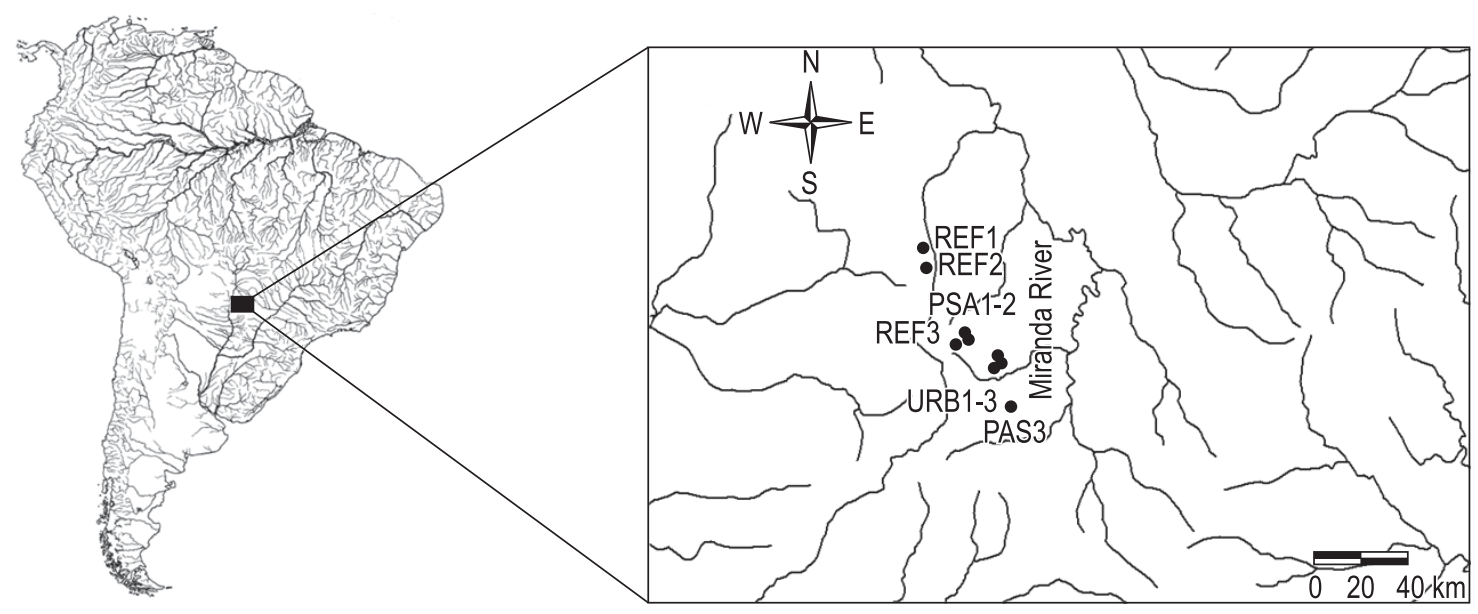

Figure 1. Location of the study area in the State of Mato Grosso do Sul, Brazil, indicating the sampled streams: REF, reference; PAS, pasture; URB, urban. 
rivers of the Bodoquena region are distributed among the municipalities of Bonito, Jardim, Bodoquena, Miranda, and Porto Murtinho. The rivers Formoso, Mimoso and Miranda are among the major drainages.

This region is characterized as a high rocky mass having altitudes of 450 to $650 \mathrm{~m}$ (Araújo et al., 1982); the vegetation ranges from open formations (Cerrado), with patches of deciduous, semideciduous and riparian forests, which vary in density depending on the drainage ecological system in which they are inserted (Jesus, 2003). The area has a typical hot tropical climate with two welldefined seasons (wet and dry), locally influenced by its topography, which reduces temperature; total rainfall is between 1,300 and $1,700 \mathrm{~mm}$ per year, with heaviest rains in summer, with December being the wettest month, and a dry season extending from May to August (Brasil, 1997).

Selected streams (Table 1) are all located in the same geomorphological region. They have a predominantly consolidated bed, a comparable size and reflect the conservation gradient of streams in the region. Those within or on the edge of the Parque Nacional da Serra da Bodoquena were considered reference (REF) (sensu Hughes, 1995) and therefore models of preserved streams, those in the pasture (PAS) can be considered as representative of an intermediate degree of conservation, and those inserted into the urban land (URB) can be considered as degraded (Table 1).

\section{Material and Methods}

Three samplings (April, May, and June/08) were done in $80 \mathrm{~m}$ length stretches in each stream. Samples were collected during the dry season when the water level of the streams was lower, permitting greater sampling efficiency. The stretches were selected on the basis of accessibility, work permits from the owners, and variability of micro-and meso-habitats.

The sampling effort was previously tested and adjusted to the size of the streams, using a seine $(1 \times 1.5 \mathrm{~m})$ and a long-handled dip net $(80 \times 40 \mathrm{~cm})$, both used by two collectors during an hour along the sampling stretch. Collected fish were fixed in $10 \%$ formalin and later transferred to ethanol $70 \%$. Permits to collect and transport specimens were granted by IBAMA (permit 11469-1, 27/11/2007). Voucher specimens were deposited in the fish collection at the Departmento de Zoologia e Botânica, IBILCE-UNESP, São José do Rio Preto (DZSJRP).

Sampling efficiency was evaluated using estimates of species richness, calculated with the computer software EstimateS 7.5 (Colwell, 2006). Estimated richness was determined by the use the ICE (Incidence-based Coverage Estimator, Lee and Chao, 1994) that calculates a correction factor using the incidence of rare species (those found in less than 11 samples), as well as the ACE (Abundance

Table 1. Classification, land cover surrounding streams, main instream habitat structures, and geographical coordinates of the stream stretches sampled in the Bodoquena Plateau, Central West of Brazil.

\begin{tabular}{|c|c|c|c|}
\hline Stream stretches & Land cover & Instream habitat structures & Geographical coordinates \\
\hline \multicolumn{4}{|l|}{ References } \\
\hline Córrego Salobrinha (REF1) & & & $\begin{array}{l}20^{\circ} 41^{\prime} 06.2^{\prime \prime} \mathrm{S} \text { and } \\
56^{\circ} 46^{\prime} 40.4^{\prime \prime} \mathrm{W}\end{array}$ \\
\hline Córrego Azul (REF2) & $\begin{array}{l}\text { forest/preserved } \\
\text { riparian forest }\end{array}$ & rocks, gravels, woody debris & $\begin{array}{c}20^{\circ} 45^{\prime} 31.3^{\prime \prime} \mathrm{S} \text { and } \\
56^{\circ} 45^{\prime} 06.8^{\prime \prime} \mathrm{W}\end{array}$ \\
\hline Córrego Taquaral (REF3) & & & $\begin{array}{c}21^{\circ} 06^{\prime} 13.7^{\prime \prime} \mathrm{S} \text { and } \\
56^{\circ} 38^{\prime} 00.3^{\prime \prime} \mathrm{W}\end{array}$ \\
\hline \multicolumn{4}{|l|}{ Pasture } \\
\hline Córrego Olaria (PAS1) & & & $\begin{array}{c}21^{\circ} 01^{\prime} 46.9^{\prime \prime} \mathrm{S} \text { and } \\
56^{\circ} 36^{\prime} 56.5^{\prime \prime} \mathrm{W}\end{array}$ \\
\hline Córrego Seco (PAS2) & $\begin{array}{l}\text { pasture/5-10 } \mathrm{m} \text { of } \\
\text { riparian forest }\end{array}$ & rocks, gravels, woody debris & $\begin{array}{c}21^{\circ} 02^{\prime} 06.4^{\prime \prime} \mathrm{S} \text { and } \\
56^{\circ} 36^{\prime} 53.7^{\prime \prime} \mathrm{W}\end{array}$ \\
\hline Córrego Mutum (PAS3) & & & $\begin{array}{c}21^{\circ} 18^{\prime} 01.1^{\prime \prime} \mathrm{S} \text { and } \\
56^{\circ} 26^{\prime} 07.7^{\prime \prime} \mathrm{W}\end{array}$ \\
\hline \multicolumn{4}{|l|}{ Urban } \\
\hline Córrego Restinga (URB1) & & & $\begin{array}{c}21^{\circ} 07^{\prime} 14.6^{\prime \prime} \mathrm{S} \text { and } \\
56^{\circ} 29^{\prime} 08.7^{\prime \prime} \mathrm{W}\end{array}$ \\
\hline $\begin{array}{l}\text { Córrego Bonito - } \\
\text { upper stretch (URB2) }\end{array}$ & $\begin{array}{l}\text { urban/2-3 } \mathrm{m} \text { of } \\
\text { riparian forest }\end{array}$ & $\begin{array}{l}\text { gravels, construction debris, } \\
\text { sand }\end{array}$ & $\begin{array}{l}21^{\circ} 07^{\prime} 48.9^{\prime \prime} \mathrm{S} \text { and } \\
56^{\circ} 28^{\prime} 51.5^{\prime \prime} \mathrm{W}\end{array}$ \\
\hline $\begin{array}{l}\text { Córrego Bonito - } \\
\text { lower stretch (URB3) }\end{array}$ & & & $\begin{array}{l}21^{\circ} 07^{\prime} 45.2^{\prime \prime} \mathrm{S} \text { and } \\
56^{\circ} 28^{\prime} 49.2^{\prime \prime} \mathrm{W}\end{array}$ \\
\hline
\end{tabular}


- based Coverage Estimator, Lee and Chao, 1994), whose correction factor uses the abundance of species having up to six individuals in the samples. Therefore, 50 randomizations without replacement were used.

Diversity and dominance in the three groups were calculated using the Shannon-Wiener $\left(\mathrm{H}^{\circ}\right)$ diversity index, whose formula is $H^{\prime}=-\Sigma$ pi. $\log _{10} \mathrm{pi}$, and the Simpson $(\lambda)$ dominance index using the formula $\lambda=\Sigma \mathrm{pi}^{2}$, where pi is the proportion of species i (Clarke and Gorley, 2006). Richness, abundance, diversity, and dominance were compared in the three groups of streams by ANOVA (one factor), supplemented by a post hoc Fisher test using Statistica 6.0 software. Species richness was also compared between stream groups using the rarefaction technique (Simberloff, 1972) in the statistical software BioDiversity Pro (McAleece et al., 1997).

To ordinate samples according to species composition, a Multidimensional Scaling Analysis of Non-Metric (NMDS) using the binary Jaccard similarity coefficient was conducted with the statistical software PRIMER 6 (Clarke and Gorley, 2006). A similar procedure was used to sort the samples according to the abundance of fish species. In this case the abundance data was transformed into square root and the similarity matrix between stretches was calculated using the Bray-Curtis coefficient. The null hypothesis that different types of land usage in the surrounding areas do not influence the quantitative structure and composition of the ichthyofauna was tested by ANOSIM, a non-parametric analysis, analogous to the variance analysis (Clarke and Warwick, 2001), processed with the statistical software PRIMER 6 (Clarke and Gorley, 2006) with 999 permutations.

In order to identify indicator species of each stream group, the Indicator Species Analysis was performed by calculating the Individual Values (IV) for all species (Dufrene and Legendre, 1997). All values were tested with 4,999 Monte Carlo permutations to verify non-random species distribution in the sampled sites; species that showed $\mathrm{p} \leq 0.05$ were considered as indicators of the sample groups. The IV calculations and statistical tests were performed on the statistical software PCOrd version 5.10 (McCune and Mefford, 2006).

\section{Results}

A quantity of 8,102 individuals representing 36 species belonging to six orders and 12 families (Table 2) was collected. Of the 36 species collected, only one is exotic (Poecilia reticulata) and was recorded only in urban sites, and another six (Characidium aff. fasciatum, Astyanax sp., Hypostomus sp., Ancistrus sp. Imparfinis sp., and Gymnotus sp.) have undefined taxonomic status, and are maybe new species or part of a complex of species within each genus, which require more detailed taxonomic revisions. Based on species richness estimation with the 27 samples over time and space, at least ten species could be added to the inventory, since values estimated by ACE and ICE indicated 45 and 46 species, respectively. According to richness estimates calculated per group, 23 or 27 fish could be registered in the reference streams (ACE and ICE, respectively) versus the 18 observed; in the pasture streams, 32 or 34 against 27 observed; in the urban there were no additional species to those 12 observed.

Species richness did not differ between groups of streams $\left(\mathrm{F}_{(2,24)}=1.16, \mathrm{p}=0.33\right)$ (Figure 2). After applying rarefaction, however, the pasture group showed a greater richness than the rest (Figure 3). On the other hand, differences in abundance were statistically significant $\left(\mathrm{F}_{(2,24)}=5.36, \mathrm{p}=0.01\right)$, with urban stretches having greater abundance than that of pasture (Fisher test, $\mathrm{p}=0.003$ ) (Figure 2). The Shannon-Wiener diversity did not differ between groups $\left(\mathrm{F}_{(2,24)}=2.65, \mathrm{p}=0.09\right)$, unlike the Simpson index $\left(\mathrm{F}_{(2,24)}=3.63, \mathrm{p}=0.04\right)$, which was higher in the urban stretches (Fisher test, $\mathrm{p}=0.03$ ) (Figure 2).

Urban stretches were more similar to each other than with those of other groups, both in species composition (Figure 4a) and in abundance (Figure 4b). Additionally, the similarity analysis (ANOSIM) revealed that the species composition of the three groups is different (Rglobal $=0.70$, $\mathrm{p}=0.001$ ), particularly between reference and urban stretches $\left(\mathrm{R}_{\text {urbxref }}=0.93, \mathrm{p}=0.002 ; \mathrm{R}_{\text {urbxpas }}=0.75\right.$, $\left.\mathrm{p}=0.001 ; \mathrm{R}_{\text {pasxref }}=0.30, \mathrm{p}=0.013\right)$. The contribution of each species to the streams groups was also different (Rglobal $=0.77, \mathrm{p}=0.001)$, again showing differences between reference and urban stretches $\left(\mathrm{R}_{\text {urbxref }}=0.99, \mathrm{p}=0.0001 ; \mathrm{R}_{\text {urbxpas }}=0.88\right.$, $\left.\mathrm{p}=0.0001 ; \mathrm{R}_{\text {pasxref }}=0.34, \mathrm{p}=0.001\right)$.

Six species were considered indicators of reference stretches, whereas two were of pasture stretches and four of urban stretches (Table 3). The occurrence and abundance of Corydoras aeneus and Poecilia reticulata, both restricted to urban stretches, were unique in showing the maximum values of IV.

\section{Discussion}

It is notable that there was no difference in the species richness and diversity among the studied 
Table 2. Collected species and relative abundance (\%) in stream stretches of the Bodoquena Plateau (REF, reference; PAS, pasture; URB, urban), MS. Classification follows Buckup et al. (2007).

\begin{tabular}{|c|c|c|c|c|}
\hline \multirow{2}{*}{$\begin{array}{l}\text { Orders and } \\
\text { families }\end{array}$} & \multirow{2}{*}{$\begin{array}{c}\text { Species and } \\
\text { authorship }\end{array}$} & \multicolumn{3}{|c|}{ Relative abundance } \\
\hline & & REF & PAS & URB \\
\hline \multicolumn{5}{|l|}{ CHARACIFORMES } \\
\hline Parodontidae & Parodon nasus Kner, 1858 & 0.11 & - & - \\
\hline \multirow[t]{2}{*}{ Crenuchidae } & Characidium aff. fasciatum Reinhardt, 1866 & 22.81 & 3.40 & 0.01 \\
\hline & Characidium zebra Eigenmann, 1909 & 2.16 & 4.22 & 0.21 \\
\hline \multirow[t]{14}{*}{ Characidae } & Brycon hilarii (Valenciennes, 1849) & 0.06 & - & - \\
\hline & Odontostilbe pequira (Steindachner, 1882) & 1.47 & 0.62 & - \\
\hline & Serrapinnus calliurus (Boulenger, 1900) & - & 0.41 & - \\
\hline & Xenurobrycon macropus Myers \& Miranda Ribeiro, 1945 & - & 0.10 & - \\
\hline & Astyanax asuncionensis Géry, 1972 & 3.06 & 0.31 & 0.13 \\
\hline & Astyanax lineatus (Perugia, 1891) & 19.35 & 8.03 & 1.71 \\
\hline & Astyanax sp. & - & 4.22 & - \\
\hline & Creagrutus meridionalis Vari \& Harold, 2001 & - & 0.72 & - \\
\hline & Hyphessobrycon luetkenii (Boulenger, 1887) & - & 8.65 & 0.05 \\
\hline & Jupiaba acanthogaster (Eigenmann, 1911) & 24.57 & 34.60 & - \\
\hline & Moenkhausia bonita Benine, Castro \& Sabino, 2004 & 2.61 & 10.61 & 0.06 \\
\hline & Moenkhausia forestii Benine, Mariguela \& Oliveira, 2009 & - & 3.09 & - \\
\hline & Piabarchus analis (Eigenmann, 1914) & - & 0.10 & - \\
\hline & Piabarchus torrenticola Mahnert \& Géry, 1985 & - & 0.21 & - \\
\hline Erythrinidae & Hoplias malabaricus (Bloch, 1794) & - & - & 0.03 \\
\hline \multicolumn{5}{|l|}{ SILURIFORMES } \\
\hline Callichthyidae & Corydoras aeneus (Gill, 1858) & - & - & 2.99 \\
\hline \multirow{7}{*}{ Loricariidae } & Farlowella paraguayensis Retzer \& Page, 1997 & - & 1.03 & - \\
\hline & Hemiloricaria lanceolata (Günther, 1868) & 0.11 & 0.93 & - \\
\hline & Loricaria prolixa Isbrücker \& Nijssen, 1978 & - & 0.31 & - \\
\hline & Hypostomus boulengeri (Eigenmann \& Kennedy, 1903) & 0.23 & 0.10 & 1.40 \\
\hline & Hypostomus cochliodon Kner, 1854 & 0.74 & 2.37 & 0.56 \\
\hline & Hypostomus sp. & 1.87 & 1.65 & - \\
\hline & Ancistrus sp. & 20.20 & 12.26 & 1.02 \\
\hline Pseudopimelodidae & Pseudopimelodus pulcher (Boulenger, 1887) & - & 0.10 & - \\
\hline \multirow[t]{4}{*}{ Heptapteridae } & Imparfinis sp. & - & 0.72 & - \\
\hline & Phenacorhamdia hoehnei (Miranda-Ribeiro, 1914) & 0.06 & - & - \\
\hline & Pimelodella gracilis (Valenciennes in d'Orbigny, 1835) & 0.45 & - & - \\
\hline & Rhamdia quelen (Quoy \& Gaimard, 1824) & - & 1.03 & 0.46 \\
\hline \multicolumn{5}{|l|}{ GYMNOTIFORMES } \\
\hline Gymnotidae & Gymnotus sp. & - & 0.10 & -0 \\
\hline \multicolumn{5}{|c|}{ CYPRINODONTIFORMES } \\
\hline Poeciliidae & Poecilia reticulata Peters, $1859^{\star}$ & - & - & 91.50 \\
\hline \multicolumn{5}{|l|}{ SYNBRANCHIFORMES } \\
\hline Synbranchidae & Synbranchus marmoratus Bloch, 1795 & 0.06 & 0.10 & 0.05 \\
\hline \multicolumn{5}{|l|}{ PERCIFORMES } \\
\hline \multirow[t]{2}{*}{ Cichlidae } & Aequidens plagiozonatus Kullander, 1984 & - & - & 0.07 \\
\hline & Crenicichla lepidota Heckel, 1840 & 0.06 & - & - \\
\hline
\end{tabular}

*Exotic species.

stream groups, indicating that these attributes appear not to be robust enough to discriminate situations of high and low impact, as already shown in other studies (Fausch et al., 1990; Casatti et al., 2006), making it necessary to seek other attributes of the aquatic biota that have a better discriminatory potential.
Average richness in each stream group varied from seven to ten species with no relation to conservation status. There are multiple factors acting on species richness, such as the longitudinal position of the sampling site, productivity and physical size of the environment (Matthews, 1998), which could restrict the number of species that each environment can have. These arrays of influences reinforce the 

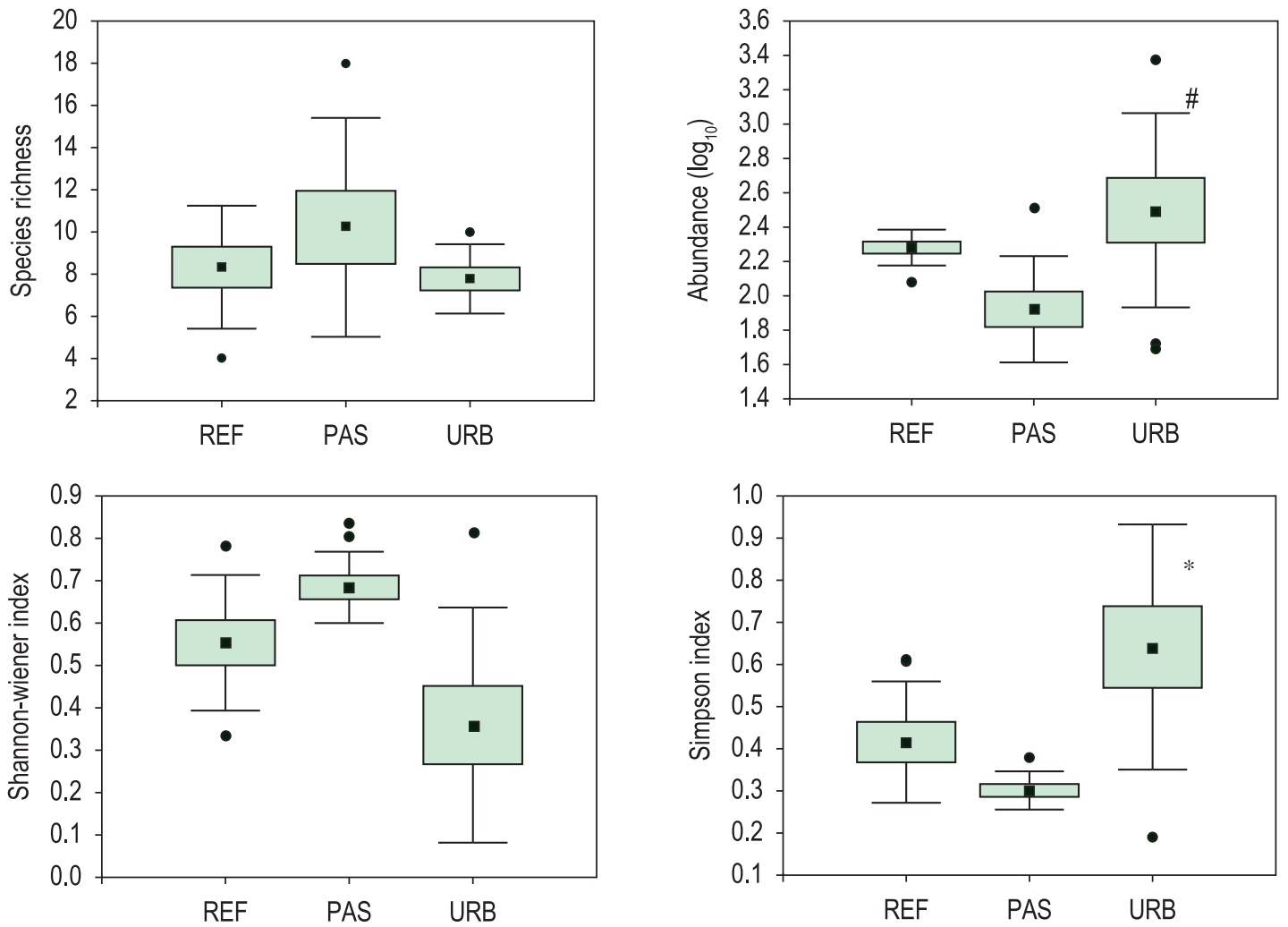

Figure 2. Graphical representation of the mean (black squares), standard deviation (box), maximum and minimum values (bars) and outliers (circles) of four ecological descriptors of the fish fauna in each group of streams (REF, reference; PAS, pasture; URB, urban). \# indicates statistically significant difference between URB group in relation to PAS, * indicates statistically significant difference between URB group compared to others.

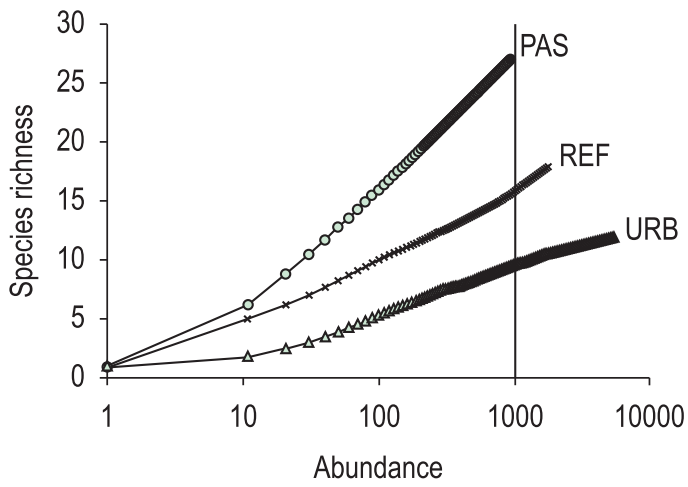

Figure 3. Rarefaction curves, constructed with 50 randomizations, using abundance data of fish fauna in each stream group (REF, reference; PAS, pasture; URB, urban). The vertical line indicates that the highest richness was recorded in the PAS group.

fact that species richness alone should not be a decisive attribute in comparisons along conservation gradients in streams. Fausch et al. (1990) discussed seven disadvantages of using richness and other indices to assess changes in fish communities due to degradation, and showed that richness may actually increase with moderate degradation due to the additions of exotic species.
Contrary to that observed for richness, the species composition, abundance and dominance between urban and other stream groups differed substantially. For example, the guppy Poecilia reticulata and the catfish Corydoras aeneus were recorded (and were dominant) only in urban streams. Guppies are small viviparous fish native to Venezuela, Barbados, Trinidad, Northern Brazil, and Guyana (Welcomme, 1988). Through accidental or deliberate release, mainly for mosquito control, this species successfully colonized at least 54 countries (FAO, 2009). Individuals are capable of surviving - and even becoming abundant - under abrupt temperature changes (Chung, 2001), low-quality habitat (Casatti et al., 2006) and hypoxia (Kramer and Mehegan, 1981; Welcomme, 1988). Due to this, this species can be considered an indicator of anthropogenic impacts (Kennard et al., 2005; Cunico et al., 2006). Corydoras aeneus belongs to a fish family with species that were recorded as tolerant to low dissolved oxygen (Mol, 1994; Araujo and Garutti, 2003), and the fact that it was registered only in urban sites suggests the presence of similar adaptation to hypoxia. 

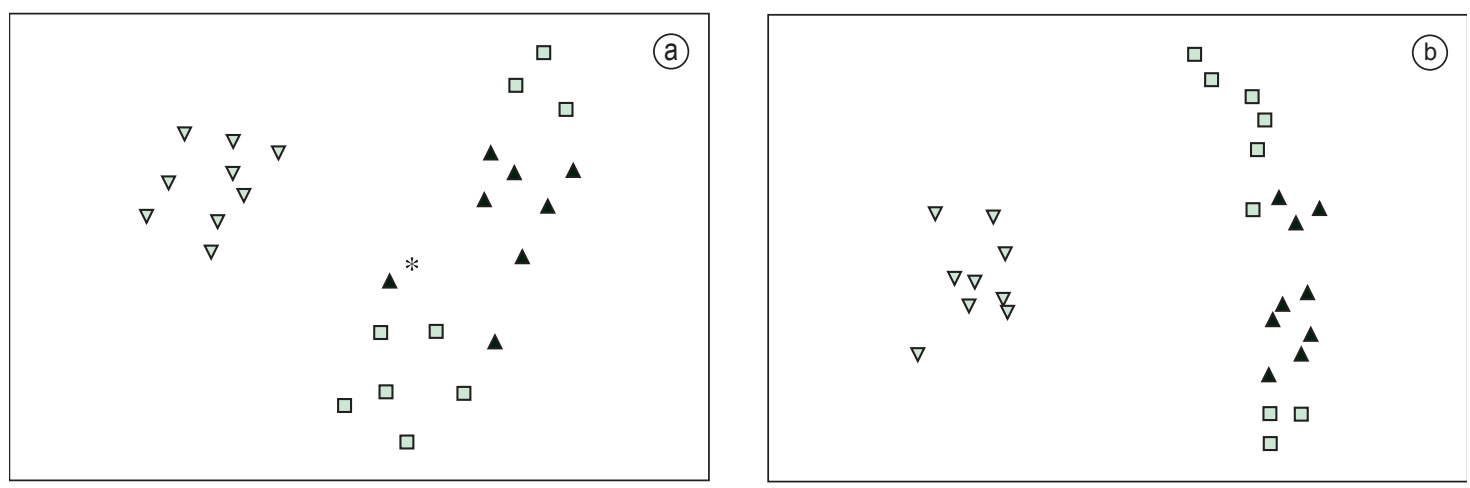

Figure 4. Bi-dimensional projection of the axes resulting from Non-Metric Multidimensional Scaling analysis (NMDS), showing the ordination of samples based on the ichthyofauna composition (a) and abundance (b) in the reference stretches (dark triangles), pasture (squares), and urban (clear triangles). The asterisk on dark triangle indicates that two samples are superimposed.

Table 3. Indicator values (IV) for species of each stream groups (REF, reference; PAS, pasture; URB, urban) and mean \pm standard deviation. MaxGroup indicates the group with maximum observed IV for each species; $p$ is the proportion of randomized trials with indicator value equal to or exceeding the observed indicator value.

\begin{tabular}{lcccc}
\hline \multicolumn{1}{c}{ Species } & MaxGroup & IV & Mean \pm SD & $p$ \\
\hline Characidium aff. fasciatum & REF & 92.4 & $36.4 \pm 10.9$ & 0.0002 \\
Ancistrus sp. & REF & 67.2 & $48.0 \pm 8.09$ & 0.0256 \\
Astyanax lineatus & REF & 66.7 & $42.1 \pm 8.18$ & 0.0096 \\
Astyanax asuncionensis & REF & 56.2 & $26.3 \pm 9.45$ & 0.0162 \\
Hypostomus sp. & REF & 44.9 & $27.3 \pm 8.19$ & 0.0380 \\
Pimelodella gracilis & REF & 44.4 & $15.5 \pm 7.57$ & 0.0242 \\
Astyanax sp. & PAS & 66.7 & $19.4 \pm 8.53$ & 0.0010 \\
Hypostomus luetkeni & PAS & 55.6 & $17.3 \pm 8.06$ & 0.0054 \\
Corydoras aeneus & URB & 100.0 & $23.7 \pm 8.74$ & 0.0002 \\
Poecilia reticulata & URB & 100.0 & $26.7 \pm 10.4$ & 0.0002 \\
Hypostomus boulengeri & URB & 93.7 & $27.9 \pm 8.78$ & 0.0002 \\
Rhamdia quelen & URB & 71.4 & $29.7 \pm 7.88$ & 0.0006 \\
\hline
\end{tabular}

Estimates of species richness indicate a greater chance to record new species in the reference group, due to the higher number of rare species in these streams. Rare species are those that frequently occur in low frequencies and/or low number of individuals in a sample (Cao et al., 1998); usually they constitute the largest component of species richness in many communities and they can be good indicators for the conservation of many aquatic groups (see authors in Cao et al., 1998). In this study, Phenacorhamdia hoehnei, Pimelodella gracilis, and Crenicichla lepidota are species that fit the rare species concept, mentioned above, and they were only recorded in the preserved stretches. In addition to these species, Parodon nasus and Brycon hilarii also showed low frequencies, but we believe that this fact was rather related to the sampling limitations of the methods used to collect these species, since Parodon nasus individuals are bottom-dwellers and Brycon hilarii are good middle-water swimmers. It is important to point out that individuals of Brycon hilarii may be numerous in tourist sites due to artificial feeding offered to attract these fish for the visitors (Sabino et al., 2005).

Results obtained through the rarefaction technique, in which richness was highest at the pasture group, may be possibly explained by the intermediate disturbance hypothesis. This theory, proposed by Connell (1978) and subsequently tested in several studies (see review by Mackey and Currie, 2000), surmise that under intermediate conditions of disturbance the highest level of diversity will be recorded. Under intermediate conditions of disturbance, there is space for coexistence of generalist and specialist species, allowing an increase in diversity or species richness (Leidy and Fiedler, 1985). However, with severe disturbance, the contribution of specialist species decreases and generalists contribute to the greater part of the fish density under these conditions. 
Evidences of this pattern were recorded in studies of various types of organisms (Connell, 1978; Souza, 1984; Petraitis et al., 1998; Lenz et al., 2004; Valdivia et al., 2005), including fishes in high degraded environments (Cunico et al., 2006; Casatti et al., 2009). The main generalist species would be Poecilia reticulata and Corydoras aeneus, which together comprised 39\% of the total fish abundance and were only recorded in the most degraded streams, while the typically specialist one would be Characidium aff. fasciatum which was the most important species for the dissimilarity of the reference group in contrast to the urban.

Although the three groups of streams are distinct one from the other with respect to composition and abundance of fish fauna, as demonstrated by analysis of similarity (ANOSIM), these differences were lower among the reference and pasture streams. This is probably due to the fact that the sampled pasture streams, despite being surrounded by grasses, showed fair to good structural instream habitat quality (i.e., diversified substrate, submerged roots of marginal vegetation, and woody debris) and a narrow stripe of riparian forest, which probably mitigates the negative impacts of the surrounding environment. In fact, several studies have emphasized the importance of riparian vegetation in mitigating the negative effects of matrix on the aquatic biota in areas dominated by grassland (Casatti et al., 2009; Lorion and Kennedy, 2009a,b).

In synthesis, our results indicate changes in fish fauna with urbanization in the surrounding water courses. The identification of Poecilia reticulata and Corydoras aeneus as indicator species in urban streams, as well as Characidium aff. fasciatum in reference streams may be useful for monitoring environmental quality of similar ecosystems. We believe that these findings are of great importance to the management of water resources and to monitoring the health of urban watersheds.

\section{Acknowledgements}

Authors thank Alexandre Pereira, Cristiane P. Ferreira, Luis G. G. Silveira for assistance in the field work, landowners for allowing access to streams on their properties, David R. Mercer for language revision, and anonymous reviewers for helpful comments. This study is part of the project "Fish as bioindicators of water quality in streams of urban and tourist areas in the Bodoquena Plateau, MS" (MCT/CNPq/CTHidro 39/2006 Taxonomy of Aquatic Organisms) and the project "Biodiversity and conservation of the ichthyofauna of the Bodoquena Plateau: index of biotic integrity, eco-physiology, and behavior applied to sustainable tourism" (FUNDECT/Call 04/2005 - Research Network). FBT and RMR receive grant from FAPESP (2008/03583-9, 2007/05400-6), LC, FL and JS from CNPq (303647/2007-8, 306988/20089, 306169/2008-8).

\section{Referências}

ARAÚJO, FG., 1998. Adaptação do índice de integridade biótica usando a comunidade de peixes para o Rio Paraíba do Sul. Revista Brasileira de Biologia, vol. 58, no. 4, p. 547-558.

ARAÚJO, RB. and GARUTTI, V., 2003. Ecology of a stream from upper Paraná river basin inhabited by Aspidoras fuscoguttattus Nijssen \& Isbrücker, 1976 (Siluriformes, Callichthyidae). Brazilian Journal of Biology, vol. 63, no. 3, p. 363-372.

ARAÚJO, HJT., SANTOS NETO, A., TRINDADE, CAH., PINTO, JCA., MONTALVÃO, RMG., DOURADO, TDC., PALMEIRA, RCB. and Tassinari, CCG., 1982. Geologia. Projeto RadamBrasil - Folha SF-21-Campo Grande, vol. 28, p. 9-124.

BRASIL, 1997. Ministério do Meio Ambiente, dos Recursos Hídricos e da Amazônia Legal. Secretaria de Coordenaçáo dos Assuntos do Meio Ambiente. Programa Nacional do Meio Ambiente. Projeto Pantanal. Plano de conservação da bacia do Alto Paraguai-PCBAP. Brasília. 4 vol.

BRASIL, 2005. Ministério do Meio Ambiente. Conselho Nacional do Meio Ambiente - CONAMA. Resolução 357. Brasília: IBAMA. 245 p.

BUCKUP, PA., MENEZES, NA. and GHAZZI, MS., 2007. Catálogo das espécies de peixes de água doce do Brasil. Rio de Janeiro: Museu Nacional. 195 p. Livros Museu Nacional.

CAO, T., WILLIAMS, DD. and WILLIAMS, NE., 1998. How important are rare species in aquatic community ecology and bioassessment? Limnology and Oceanography, vol. 43, no. 7, p. 1403-1409.

CASATTI, L., SILVA, AM., LANGEANI, F. and CASTRO, RMC., 2006. Stream fishes, water and habitat quality in a pasture dominated basin, Southeastern Brazil. Brazilian Journal of Biology, vol. 66, no. 2B, p. 681-696.

CASATTI, L., FERREIRA, CP. and CARVALHO, FR., 2009. Grass-dominated stream sites exhibit low fish species diversity and dominance by guppies: an assessment of two tropical pasture river basins. Hydrobiology, vol. 632, no. 1, p. 273-283.

CHUNG, KS., 2001. Critical thermal maxima and acclimation rate of the tropical guppy Poecilia reticulata. Hydrobiology, vol. 462, no. 1-3, p. 253-257. 
CLARKE, KR. and WARWICK, RM., 2001. Change in marine communities: an approach to statistical analysis and interpretation. Plymouth: Plymouth Marine Laboratory. $144 \mathrm{p}$.

CLARKE, KR. and GORLEY, RN., 2006. PRIMER v5: User manual/tutorial. Plymouth: Plymouth Marine Laboratory. $91 \mathrm{p}$.

COLWELL, RK., 2006. EstimateS 7.5 - Statistical estimation of species richness and shared species from samples. Storrs: University of Connecticut. 20 p. Software.

CONNELL, JH., 1978. Diversity in tropical rain forests and coral reefs. Science, vol. 199, no. 4335, p. $1302-1310$.

CUNICO, AM., AGOSTINHO, AA. and LATINI, JD., 2006. Influência da urbanização sobre as assembléias de peixes em três córregos de Maringá, Paraná. Revista Brasileira de Zoologia, vol. 23, no. 4, p. 1101-1110.

DUFRENE, M. and LEGENDRE, P., 1997. Species assemblages and indicator species: the need for a flexible asymmetrical approach. Ecological Monographs, vol. 67 , no. 3, p. 345-366.

FAUSCH, KD., LYONS, J., KARR, JR. and ANGERMEIER, PL., 1990. Fish communities as indicator of environmental degradation. American Fisheries Society Symposium, vol. 8, p. 123-144.

Food and Agriculture Organization of the United Nations - FAO, (s/d). Database on introduction of aquatic species - DIAS. Avaible from: <http://www. fao.org/fishery/introsp/search>. Access in: $18 \mathrm{de}$ Março de 2009.

GONÇALVES, JLM., NOGUEIRA Jr., LR. and DUCATTI, F., 2003. Recuperação de solos degradados. In KAGEYAMA, PY., OLIVEIRA, RE., MORAES, LFD., ENGEL, VL. and GANDARA, FB. orgs. Restauração ecológica de ecossistemas naturais. Botucatu: Fundação de Estudos e Pesquisas Agrícolas e Florestais. p. 111-163.

HUGHES, RM., 1995. Defining acceptable biological status by comparing with reference conditions. In Davis, WS. and Simon, TP., eds. Biological assessment and criteria: tools for water resource planning and decision making. Boca Raton: CRC Press. p. 31-47.

JESUS, F., 2003. Classificaçâo dos ecossistemas aquáticos do Pantanal e da bacia do Alto Paraguai. Brasília: The Nature Conservancy. p. 136.

KENNARD, MJ., ARTHINGTON, AH., PUSEY, BJ. and HARCH, BD., 2005. Are alien fish a reliable indicator of river health? Freshwater Biology, vol. 50, no. 1, p. 174-193.

KRAMER, DL. and MEHEGAN, JP., 1981. Aquatic surface respiration, an adaptative response to hypoxia in the guppy, Poecilia reticulata (Pisces, Poeciliidae). Environmental Biology of Fishes, vol. 6, no. 3, p. 299-313.
LEE, SM. and CHAO, A., 1994. Estimating population size via sample coverage for closed capture-recapture models. Biometrics, vol. 50, no. 1, p. 88-97.

LENZ, M., MOLIS, M. and WAHL, M., 2004. Testing the intermediate disturbance hypothesis: response of fouling communities to various levels of emersion intensity. Marine Ecology - Progress Series, vol. 278, p. 53-65.

LEIDY, RA. and FIEDLER, PL., 1985. Human disturbance and patterns of fish species diversity in the San Francisco Bay drainage, California. Biological Conservation, vol. 33, no. 3, p. 247-267.

LORION, CM. and KENNEDY, BP., 2009a. Riparian forest buffers mitigate the effects of deforestation on fish assemblages in tropical headwater streams. Ecological Applications, vol. 19, no. 2, p. 468-479.

LORION, CM. and KENNEDY, BP., 2009 b. Relationships between deforestation, riparian forest buffers and benthic macroinvertebrates in neotropical headwater streams. Freshwater Biology, vol. 54, no. 1, p.165-180.

LOWE-McCONNELL, RH., 1987. Ecological studies in tropical fish communities. Cambridge: University Press. 382 p.

MACKEY, RL. and CURRIE, DJ., 2000. A reexamination of the expected effects of disturbance on diversity. Oikos, vol. 88, no. 3, p. 483-493.

MATTHEWS, WJ., 1998. Patterns in freshwater fish ecology. Norwell: Kluwer Academic Publishers. $756 \mathrm{p}$.

McALEECE, N., LAMBSHEAD, PJD., PATERSON, GLJ. and GAGE, JG., 1997. Biodiversity Professional - Beta-Version. London: The Natural History Museum and the Scottish Association for Marine Sciences.

McCUNE, B. and MEFFORD, MJ., 2006. PC-ORD Multivariate analysis of ecological data. Version 5.10. Oregon: MjM Software.

MOL, JH., 1994. Effects of salinity on distribution, growth and survival of three neotropical armoured catfishes (Siluriformes - Callichthyidae). Journal of Fish Biology, vol. 45, no. 5, p. 763-776.

PETRAITIS, PS., LATHAM, RE. and NIESENBAUM, RA., 1998. he maintenance of species diversity by disturbance. Quarterly Review of Biology, vol. 64, no. 4, p. 393-418.

PLAFKIN, JL., BARBOUR, MT., PORTER, KD., GROSS, SK. and HUGHES, RM., 1989. Rapid Bioassessment protocols for use in streams and rivers: benthic macroinvertebrates and fish. Washington, D.C: EPA. 181 p.

SABINO, J., 2002. Planalto da Bodoquena: natureza em estado de graça. Revista Os Caminhos da Terra, ano 11 , edição 125 , p. 58-65. 
SABINO, J., 2005. Planalto da Bodoquena: no domínio das águas claras. Revista Terra da Gente, vol. 9, no. 1, p. 27-38.

SABINO, J. and TRAJANO, E., 1997. A new species of blind armoured catfish, genus Ancistrus, from caves of Bodoquena region, Mato Grosso do Sul, southwestern Brazil. Revue Française d'Aquariologie, vol. 24, no. 3-4, p. 73-78.

SABINO, J., MEDINA Jr., PB. and ANDRADE, LP., 2005. Visitantes mal-comportados e piraputangas obesas: a pressão da visitação pública sobre Brycon hilarii no Balneário Municipal de Bonito, Mato Grosso do Sul, Brasil. In Anais Encontro Nacional de Inovação Científica para o Homem do Século XXI, IV ENPIC, 19 a 21 de outubro. Campo Grande: UNIDERP. p. 321-332.

SAUNDERS, DL., MEUUWIG, JJ. and VINCENT, ACJ., 2002. Freshwater protected areas: strategies for conservation. Conservation Biology, vol. 16, no. 1, p. 30-41.

SCREMIN-DIAS, E., POTT, VJ., HORA, RC. and SOUZA, PR., 1999. Nos jardins submersos da Bodoquena: guia de identificação de plantas aquáticas de Bonito e regiāo. Campo Grande: Editora da UFMS. 160 p.

SIMBERLOFF, DS., 1972. Properties of the rarefaction diversity measurement. American Naturalist, vol. 106, no. 964 , p. 414-418.
SOUZA, WP., 1984. The role of disturbance in natural communities. Annual Review of Ecology and Systematics, vol. 15, p. 353-391.

VALDIVIA, N., HEIDEMANN, A., THIEL, M., MOLIS, M. and WAHL, M., 2005. Effects of disturbance on the diversity of hard-bottom macrobenthic communities on the coast of Chile. Marine Ecology Progress Series, vol. 299, p. 45-54.

WELCOMME, RL., 1988. International introductions of inland aquatic species. Rome: FAO. 318. Paper T294.

WILLINK, PW., CHERNOFF, B., ALONSO, LE., MONTANBAULT, JR. and LOURIVAL, R., 2000. A biological assessment of the aquatic ecosystems of the Pantanal, Mato Grosso do Sul, Brazil. Washington, D.C.: RAP. 306 p. Bulletin of Biological Assessment, no. 18.

YODER, CO. and RANKIN, ET., 1994. Biological criteria program development and implementation in Ohio. In DAVIS, WS. and SIMON, TP. eds. Biological assessment and criteria: tools for water resource planning and decision making. Boca Raton: CRC Press. p. 109-114.

Received: 27 January 2010

Accepted: 15 April 2010 